\title{
EVALUATION OF LAND COVER CHANGES AFTER EXTRAORDINARY WINDSTORM BY USING THE LAND COVER METRICS: A CASE STUDY ON THE HIGH TATRAS FOOTHILL
}

\begin{abstract}
FALŤAN, V., BÁNOVSKÝ, M., BLAŽEK, M. (2011): Evaluation of land cover changes after extraordinary windstorm by using the land cover metrics: a case study on the high Tatras foothill. Geografie, 116, No. 2, pp. 156-171. - On the 19th November 2004, a wind disaster caused extensive damages, especially in the forests of the Tatra National Park. Despite that windstorm consequences of natural processes impact the spatial structure of landscape excessively, their studies have been subject only to a minor interest so far. The aim of this paper is to characterize the land cover changes in the Štrbské Pleso - Tatranská Lesná area, before the wind disaster and after its impacts have been processed. We also analyze the relationship between wind-caused damages to the vegetation and the natural landscape structure, using various landscape metrics.

KEY WORDS: land cover changes - CORINE - wind disaster - land cover metrics - natural landscape structure - High Tatras - Slovakia.
\end{abstract}

\section{Introduction}

Wind disasters affect world forests in the areas situated in tropical, temperate and boreal climate. Recognizing the impact of wind on the forest cover by using the geographical information systems (GIS) for evaluation of the level of their damage is among the main topics of the recent landscape-ecological, biogeographical and forestry research. Wind disasters cause windthrow and ruptures, affect the fragmentation of landscape and affect highly the land image as result of an individual process of perception as an expression of physiological perception and the psychosocial structure of personality (Nohl 2001).

The spatial pattern of damage is influenced by both biotic and abiotic factors. Biotic factors that influence severity of damage include stem size, species, stand conditions and the presence of pathogens. Abiotic factors that influence severity of damage include the intensity of the wind, previous disturbance, topography, and soil characteristics (Everham, Brokaw 1996). Research of wind regimes was carried out by Schulte et al. (2005). The most important type of disturbances in the forests of Central Europe are windthrows associated with a direct disturbance of soils (Ulanova 2000). Whirlwinds in High Tatras are periodical and they affect ecosystems of the spruce forests in the foothill on a long term basis. The situation in forests belonging to the Tatra National Park (TANAP), caused by the windstorm on the 19th November 2004, was exceptional by its unusual dimension. The area of TANAP was affected by 
winds with speeds reaching up to $200 \mathrm{~km}$ an hour. Proper characteristics of the secondary landscape structure (of a real state of surface segments of land systems) along with a map expression in the large scale stand for important information for an evaluation of the recent state of the damaged area, land systems and landscape planning.

The aim of our paper is to give a characteristics of spatial structure changes of land cover in the studied area of the High Tatras foothill in the Štrbské Pleso - Tatranská Lesná site, as based upon the analysis of the state of landscape structure before the wind disaster in November 2004, and after its consequences have been processed. For this process, we use the CORINE Land Cover methods and selected land cover metrics. We also analyse dependence of the changes on natural landscape structure. The natural landscape is reconstructed as a hypothetic state, which existed before the human impact, but related to the present climatic conditions (Otahel et al. 2008).

We focused on verification of our working hypotheses: 1 . Vegetation of the same age in the former production coniferous forests (with the majority of spruce) in the Tatras foothill were damaged more severely than natural vegetation and the values of landscape metrics differentiated. 2. Landscape systems of lee slope areas with high slope gradients were less vulnerable to the wind disaster than systems of moraines, glacifluvial and polygenetic forms. We verified our hypotheses at the level of geochores. The properties of choric spatial units result from the combination of topic elements, as well as their arrangement in space. The term 'geochore' means a geographically-defined or limited unit. Common sources of data are: soil maps, geological maps, maps of vegetation and land use (Bastian 2000).

Land cover is defined as a material expression of natural and socio-economic processes, related in particular to land use on the Earth's surface. It differentiates spatially through its physiognomic and morphostructural features and it indicates the intensity of existing processes and changes in the landscape (Feranec, Otahel 1999).

Windstorm impacts of natural processes significantly adjust the landscape structure; however, they rather lack an attention, despite their uniqueness and a considerable change of landscape image that they bring. Siu-Ngan Lam (2008) focused on the identification of areas affected by natural disaster through classified remote sensing pictures through an example of the hurricane Catherine. Dobrovolný, Keprtová (2006) analyzed the spatial features of damages caused by wind calamities in Czech lands since 1500. Zielonka, Malcher (2009) investigated dynamics of a mountain mixed forest under wind disturbances in the Tatra Mts., Faltan, Saksa (2007) and Faltan, Bánovský (2008) presented land cover changes in selected areas of the Tatras foothill.

Land cover metrics characterize the structure of spatial distribution of areal patches in landscape. Their use has been discussed by Forman, Godron (1993). A detailed discussion of the use of land cover metrics in the planning praxis has been given by Leitão, Ahern (2002). Patch is considered a basic object of analysis. It represents a spatial unit of the Earth's surface with its own genesis, it is differentiated from its surrounding through the physiognomic characteristic, and it represents an important feature of landscape structure (McGarigal 2002) and is used in creating the ecological plans of landscape (Zhang, Wang 2006). Its definition is similar to area of land cover. 


\section{Methods}

The area of study takes place between Štrbské Pleso and Tatranská Lesná (Fig. 1) in coniferous zone. Its size is $56 \mathrm{~km}^{2}$ and it represents all types of land systems of the area mostly affected by the calamity. The range of the studied area was limited by personal and financial limits of the project. Four permanent post-calamity research sites of the State Forests of TANAP, with a management of which cooperation has been established, are present there. The area lies at the boundary of the geomorphologic unit of Tatras, the subunit of East Tatras and the part of High Tatras and the geomorphologic unit of Podtatranská basin (Subtatra Basin), the sub-units of Popradská kotlina (Poprad Basin) and Tatranské podhorie (Tatra Foothills; Mazúr, Lukniš 1980). A considerable segment of the area is a part of several national natural reservations.

We have processed the map of land cover and the characteristics of its typological units through the methodological framework for the 3rd and 4th level of CORINE Land Cover (CLC) project classes (Feranec, Otahel' 1999, 2001). We have chosen units present in the studied area and adjusted names of some according to individual features of the area.

Aerial photographs from the year 2005 (Vysoké Tatry - atlas ortofotomáp 2006) have been used for a primary identification of patterns of classes of land cover and their boundaries by a visual (analogue) interpretation in the scale of 1:25,000. The 2004 map has been modified with the use of materials of the Vojenský kartografický ústav Harmanec (Vysoké Tatry - ortofotomapa 2004). Boundaries and content of individual sites were updated during the field mapping between 2006 and 2008 with the GPS technology. For the identification of the classes of the third level (in selected cases, depending on a relevance for the research, also of the fourth level), we have followed characteristics of the morphostructural and physiognomic features that distinguish respective

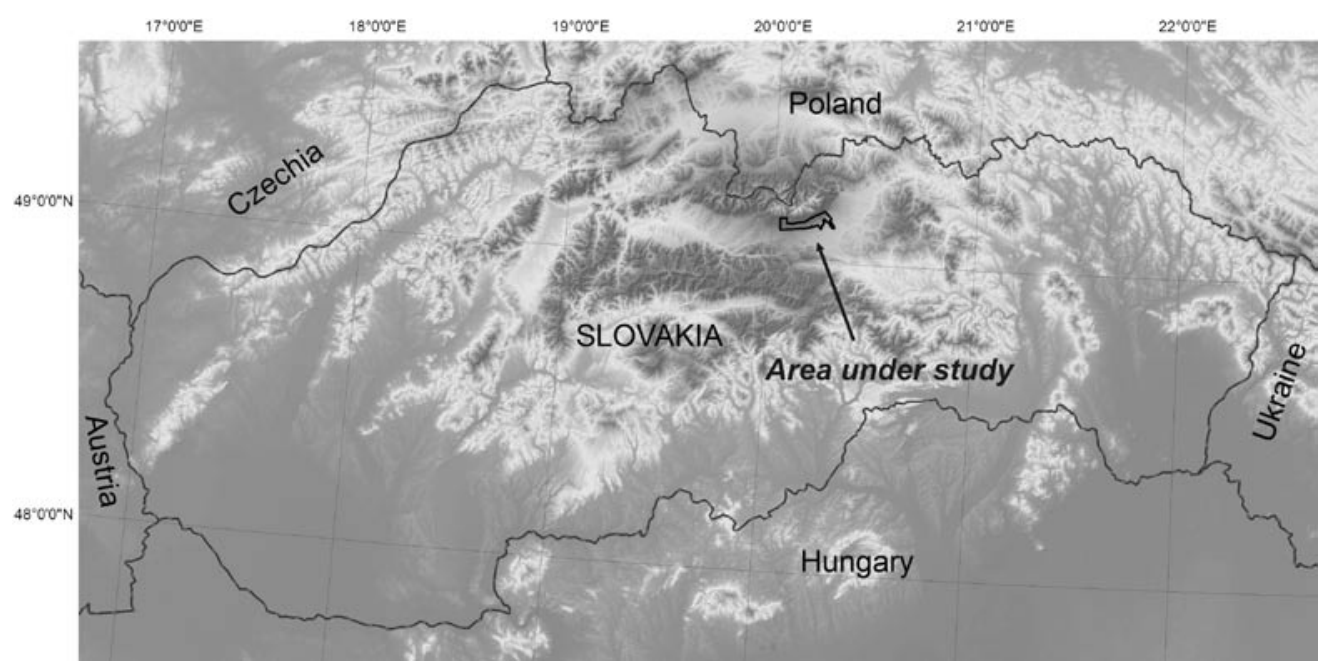

Fig. 1 - Situation map of study area 
sites. This arrangement also respects territorial specificities, such as division of chopped areas in the processed localities according to the proportion of standing trees.

We have analyzed the characteristics of typological units of land cover of the studied area and we have displayed their structure in using the GIS programmes ArcView 3.2 and ArcInfo 9.2. Final maps were produced in the $1: 25,000$ scale, they are presented in approximately 1:70,000 scale in this paper. Map digitalisation enabled us to use the existing database for consequential analysis focusing on the quantitative characteristics of land cover changes, such as description of the number of polygons in respective map units, and their absolute or relative extent, for instance. Furthermore, we have applied selected relevant procedures of the quantitative analysis of landscape through metrics. Areas were calculated using function "Calculate Geometry" in ArcInfo.

The following variables enter our analysis as retrieved by the GIS tools: $P$ - Surface area of all patches of a selected class of land cover; $N P$ - number

Table 1 - Statistical characteristics of landcover changes in selected area after the wind calamity

\begin{tabular}{|c|c|c|c|c|c|}
\hline \multirow[t]{2}{*}{ Categories of landcover } & \multicolumn{2}{|c|}{ Area (ha) } & \multicolumn{2}{|c|}{ Landcover changes } & \multirow{2}{*}{$\begin{array}{l}\text { Changed } \\
\text { area }(\%)\end{array}$} \\
\hline & before & after & area (ha) & $\operatorname{area}(\%)$ & \\
\hline Discontinuous urban fabric & 117.36 & 117.36 & 0.00 & 0.00 & 0.00 \\
\hline $\begin{array}{l}\text { Road and rail networks and } \\
\text { associated land }\end{array}$ & 61.17 & 62.77 & 1.60 & 2.62 & 0.04 \\
\hline Green urban areas & 19.80 & 19.41 & -0.40 & 2.00 & 0.01 \\
\hline Sport and leisure facilities & 31.39 & 31.60 & 0.21 & 0.67 & 0.01 \\
\hline Non-irrigated arable lands & 1.80 & 4.08 & 2.29 & 127.28 & 0.06 \\
\hline Grasslands & 175.52 & 110.20 & -65.33 & 37.22 & 1.58 \\
\hline Broad-leaved forest & 76.71 & 48.37 & -28.34 & 36.94 & 0.69 \\
\hline Coniferous forest & $4,543.78$ & 917.14 & $-3,626.64$ & 79.82 & 87.74 \\
\hline Mixed forests & 350.44 & 33.13 & -317.31 & 90.55 & 7.68 \\
\hline Dwarf pine & 23.12 & 23.12 & 0.00 & 0.00 & 0.00 \\
\hline Transitional woodland-scrubs & 202.04 & 292.97 & 90.93 & 45.00 & 2.20 \\
\hline Complete clearings & 0.00 & $3,075.78$ & - & - & - \\
\hline $\begin{array}{l}\text { Complete clearings with } \\
\text { individual trees }\end{array}$ & 0.00 & 629.34 & - & - & - \\
\hline $\begin{array}{l}\text { Coniferous forest with local } \\
\text { clearings }\end{array}$ & 0.00 & 152.18 & - & - & - \\
\hline Unprocessed calamity & 0.00 & 87.19 & - & - & - \\
\hline Bare rocks & 0.38 & 0.38 & 0.00 & 0.00 & 0.00 \\
\hline Peatbogs & 1.57 & 1.73 & 0.16 & 10.34 & 0.00 \\
\hline Water bodies & 21.68 & 21.68 & 0.00 & 0.00 & 0.00 \\
\hline$\sum$ & $5,626.77$ & $5,626.77$ & $4,133.19$ & 73.46 & 100.00 \\
\hline
\end{tabular}


of land cover patches in the area; TLA - size of the area; $E$ - edge of particular land cover patches; $T E$ - edge of all land cover patches. We have considered changes in number of land cover patches and the following relevant land cover metrics: mean patch size $\left(M P S=\sum P / N P\right)$ characterizes the extent of fracture of the landscape spatial structure; patch density $(P D=N P / T L A)$ describes the level of the horizontal segmentation of landscape and reflects the level of fragmentation of the secondary landscape structure; median patch size represents the middle value of sizes of patches of respective land cover types; total edge $\left(T E=\sum E\right)$ gives an important information about homogeneity/heterogeneity of the area that can be used through the following procedures; edge density $(E D=T E / T L A)$ is important for evaluation of heterogeneity of contact parts of land cover patches, or ecotones; mean patch edge $(M P E=T E / N P)$ describes the average edge of land cover patches; mean shape index $(M S I=(\Sigma T E / \sqrt{ } P S) /(N P)$ : a higher value of this index indicates irregularity of the patches shape.

Furthermore, we discussed the level of damage in forests and semi-natural areas in relation to diversity of the natural landscape structure. For more detail, we divided typological units of land systems (Miklós, Izakovičová 2006), based on analyses of the most detailed available maps of potential natural vegetation (Michalko, Berta 1980), landforms (Lukniš 1968), geological bedrock (Nemčok et al. 1994), and the outputs of our complex physical-geographical fieldwork and the description of 260 field sites ("tesseras") using the 1:25,000 scale. Further explication is given by Minár et al. (2009). We assigned 14 types of geochores. Then, we analyzed the rate of relative damage to areas of forests and semi-natural vegetation by wind as depending on the natural land structure type.

\section{Results}

3.1. Changes of land cover after the wind disaster

This subchapter presents a summary of location of the mapping units of land cover in the studied area in 2004 and after processing the impacts of the windstorm (Fig. 2).

Artificial surfaces represent the most affected segments of cultural landscape by human activities. Discontinuous urban fabric is concentrated mainly in the Tatra settlements. Disaster has damaged several buildings, but the total size of the area remained unchanged (Table 1). It can be expected that it will be even expanded after planned activities of investing developers. Road and railway networks and associated land comprises particularly of the Cesta Slobody road and the parallel narrow-gauge railway. They are both displayed as line features with unchanged size. Green urban areas are scattered in both central and peripheral areas of settlements. Sport and leisure facilities are represented primarily by ski slopes in North from Štrbské Pleso and Starý Smokovec.

Agricultural areas are areas with different modes of cultivation. Non-irrigated arable lands are present in four fragments in South from Starý Smokovec and its size has increased slightly. Grasslands are areas used for skiving 
(meadows) and grazing (pastures). Their number decreased in half and their area size has diminished of 70 ha. In many cases, they have been used as assemblages of processed wood mass and they have been degraded.

Forests and semi-natural areas have been affected by the wind most viciously. Broad-leaved forests are represented by remnants of initial natural vegetation, especially by communities of Alnenion glutinoso-incanae Oberd. 1953. Comparing to the pre-calamity state, their size has diminished of almost 30 ha. Coniferous forests represented most of the vegetation. Spruce monocultures in the central and lower-based areas dominated, they were considerably damaged in 2004. In higher areas of National Natural Reservations, the level of vegetation damage is lesser with natural generic structure dominating, especially communities of Eu-Vaccinnio-Abietion Oberd. 1957 and local presence of Vaccinio-Abietenion Oberd. 1962 and Piceion excelsae Pawlowski in Pawlowski et al. 1928. Before 2004, they represented more than $80 \%$ of the area impacted by windstorm, now it is just less than $16 \%$. Coniferous forests with local clearings have been assigned separately as one of specific mapping units characterizing state of land cover of the studied area after the wind disaster in details. They are most numerous in surrounding of Štrbské Pleso and Vyšné Hágy. Mixed forests existed as isolated sites before the calamity. Now, they are present only in the lower parts of the area in Southeast. Transitional woodland-shrubs are successive stages between grasslands and forests. Their size is larger of more than 90 ha now, but their number has increased almost twice. Complete clearings represent more than half of the size of the area. They are covered especially by Calamagrostis villosa and Chamaerion angustifolium. Complete clearings with individual trees often create a "buffer" zone for coniferous woods. They are mostly present in the area of Štrbské Pleso - Vyšné Hágy and around Starý Smokovec. Unprocessed wood mass makes only about 90 ha of the whole studied area. The largest such site left for self-evolution lies in North of Tatranská Lesná. Bare rocks are represented only by one area in North of Štrbské Pleso in the dwarf pine vegetation.

Wetlands are an important feature of the landscape structure. Peatbogs are represented by three sites of wetlands (Natural Reservation Rašelinisko) near Štrbské Pleso. Water bodies, especially natural streams and lakes, are also among ecology-stabilizing features. Water courses in the area are Studený potok, Štiavnik, Slavkovský potok, Velický potok, Batizovský potok, Háganský

Table 2 - Land cover metrics of the whole study area

\begin{tabular}{|lrr|}
\hline Land cover metrics & Before calamity & After calamity \\
\hline 1. Number of patches (NUMP) & 393 & 665 \\
2. Mean patch size (ha; MPS) & 14.32 & 8.44 \\
3. Median patch size (ha; MEDPS) & 1.10 & 1.42 \\
4. Patch Size Standard Deviation (PSSD) & 77.82 & 38.36 \\
5. Total edge (m; TE) & $731,551.06$ & $1,100,785.82$ \\
6. Edge density (m/ha; ED) & 130.01 & 195.63 \\
7. Mean patch edge (m; MPE) & $1,861.45$ & $1,655.32$ \\
8. Mean shape index (MSI) & 24.82 & 22.07 \\
9. Patch density (number of patches/ha; PD) & 0.07 & 0.12 \\
\hline
\end{tabular}




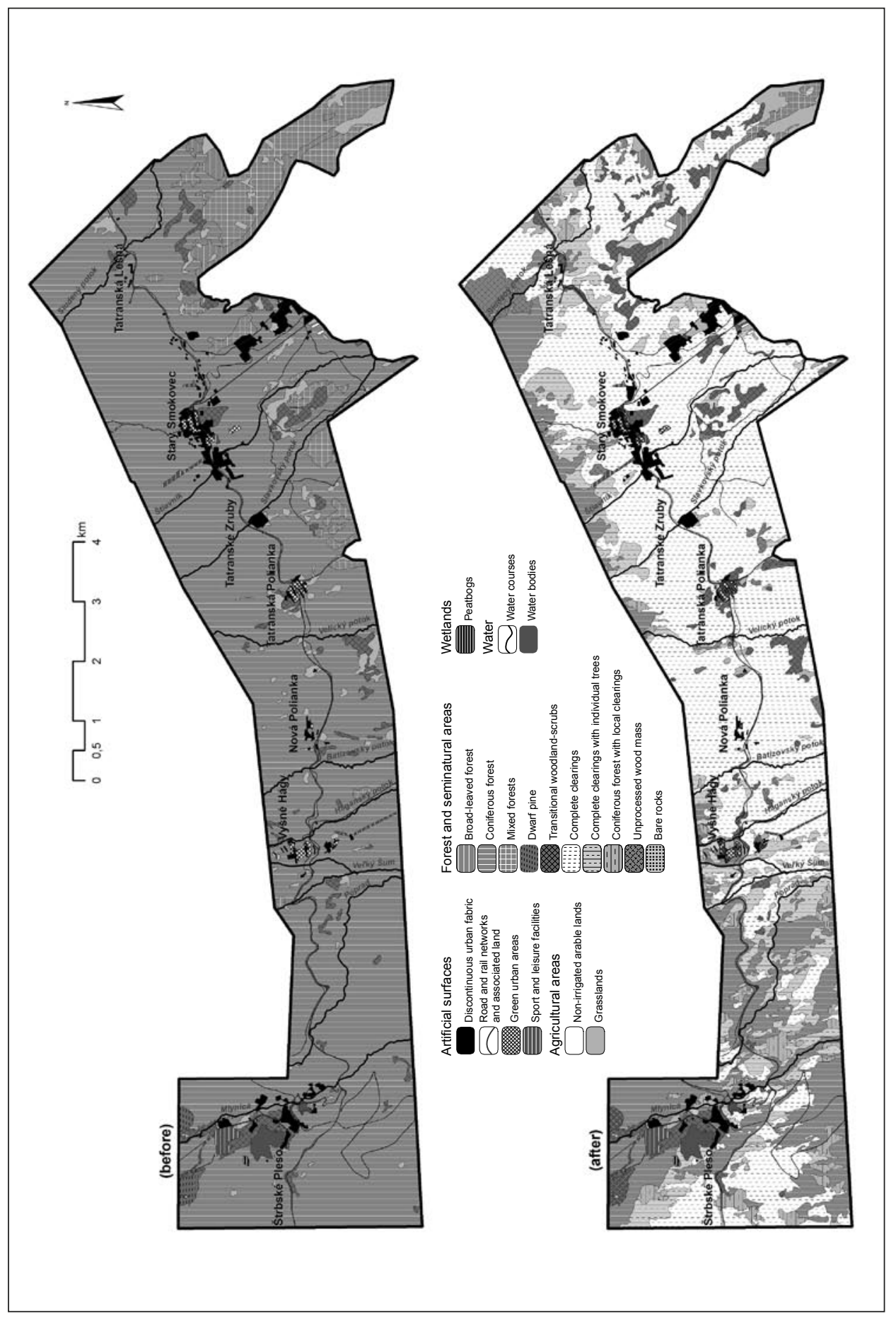

Fig. 2 - The land cover before and after the wind calamity 


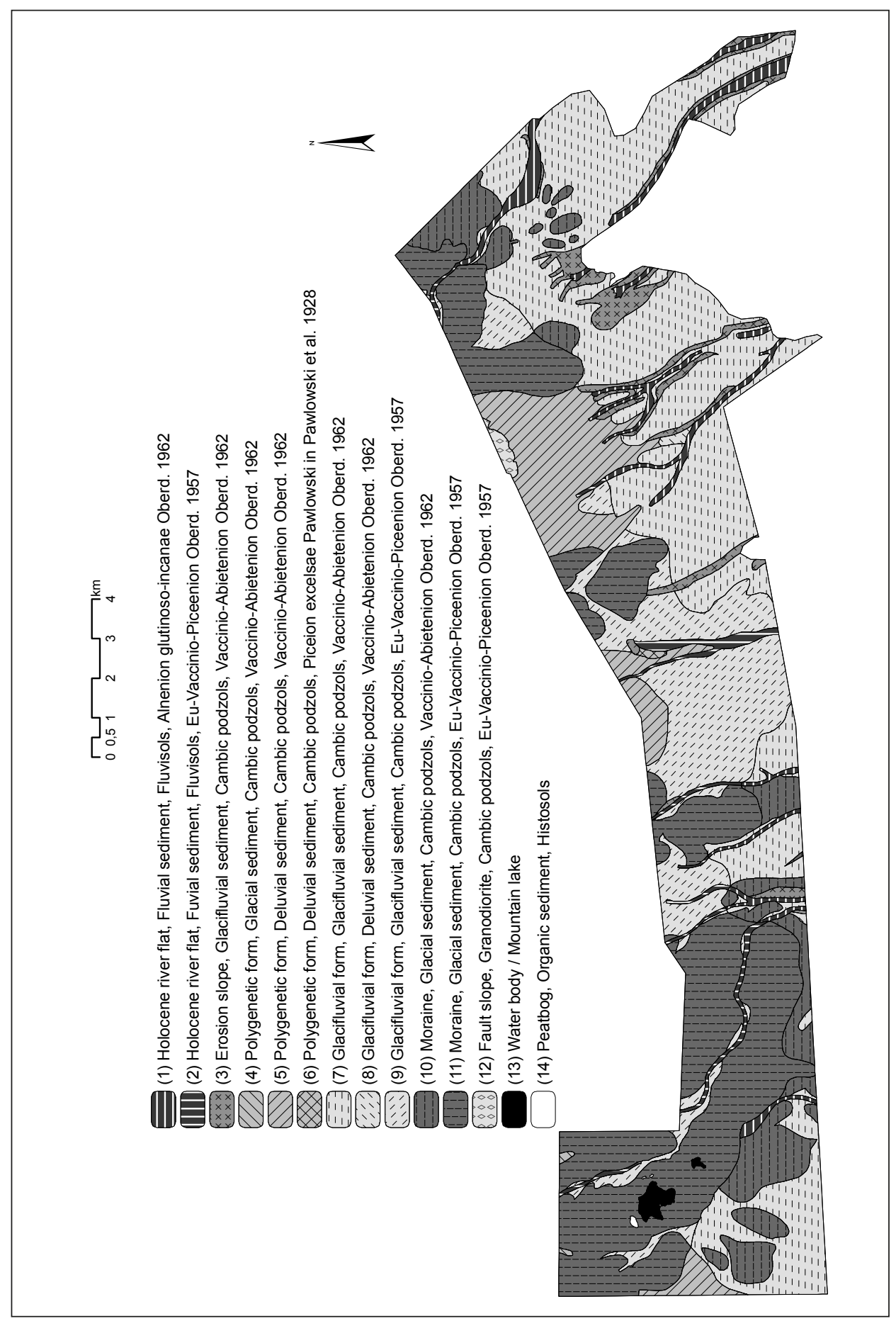

Fig. 3 - Natural landscape structure 
Table 3 - Land cover metrics of particular classes of land cover

\begin{tabular}{|c|c|c|c|c|c|c|c|c|}
\hline \multirow[t]{2}{*}{ Categories of land cover } & \multicolumn{2}{|c|}{ NUMP } & \multicolumn{2}{|c|}{ MPS } & \multicolumn{2}{|c|}{ MEDPS } & \multicolumn{2}{|c|}{ PSSD } \\
\hline & before & after & before & after & before & after & before & after \\
\hline Discontinuous urban fabric & 99 & 99 & 1.19 & 1.19 & 0.29 & 0.29 & 2.46 & 2.46 \\
\hline Road and rail networks and assoc. land & 14 & 14 & 4.37 & 4.48 & 2.54 & 2.07 & 3.90 & 3.56 \\
\hline Green urban areas & 13 & 14 & 1.52 & 1.39 & 0.93 & 1.02 & 1.44 & 1.06 \\
\hline Sport and leisure facilities & 11 & 12 & 2.85 & 2.63 & 1.14 & 0.83 & 4.85 & 4.69 \\
\hline Non-irrigated arable lands & 3 & 4 & 0.60 & 1.02 & 0.59 & 0.80 & 0.07 & 0.52 \\
\hline Grasslands & 104 & 53 & 1.69 & 2.08 & 0.94 & 0.87 & 2.83 & 4.39 \\
\hline Broad-leaved forest & 7 & 5 & 10.96 & 9.67 & 2.51 & 1.85 & 16.67 & 13.02 \\
\hline Coniferous forest & 52 & 79 & 87.38 & 11.61 & 4.66 & 2.03 & 196.83 & 30.71 \\
\hline Mixed forests & 19 & 2 & 18.44 & 16.56 & 6.14 & 16.56 & 42.77 & 12.31 \\
\hline Dwarf pine & 2 & 2 & 11.56 & 11.56 & 11.56 & 11.56 & 3.48 & 3.48 \\
\hline Transitional woodland-scrubs & 64 & 112 & 3.16 & 2.62 & 1.56 & 1.24 & 4.08 & 4.08 \\
\hline Complete clearings & - & 88 & - & 34.95 & - & 3.21 & - & 96.17 \\
\hline Complete clearings with individual trees & - & 120 & - & 5.24 & - & 2.00 & - & 8.44 \\
\hline Coniferous forest with local clearings & - & 42 & - & 3.62 & - & 2.22 & - & 3.39 \\
\hline Unprocessed calamity & - & 13 & - & 6.71 & - & 1.62 & - & 15.77 \\
\hline Bare rocks & 1 & 1 & 0.38 & 0.38 & 0.38 & 0.38 & 0.00 & 0.00 \\
\hline Peatbogs & 2 & 3 & 0.78 & 0.58 & 0.78 & 0.16 & 0.64 & 0.64 \\
\hline Water bodies & 2 & 2 & 10.84 & 10.84 & 10.84 & 10.84 & 8.82 & 8.82 \\
\hline
\end{tabular}

potok, Vel'ký and Malý Šum, and Poprad with feeders, all mapped as line features. Water bodies are represented especially by Štrbské pleso.

\subsection{Land cover metrics evaluation}

Analyzing the land cover metrics for all patches, the overall landscape structure is more fragmented after the calamity (Table 2). Further, we briefly evaluate changes of land cover metrics for particular classes of land cover (Table 3). Number of patches of the initially most numerous mapping unit - coniferous forests - was not high, it had been 52 and it raised to 79 after the calamity and reduction of size of the unit and following fragmentation. Mean patch size is highest in complete clearings, it decreased in coniferous forests and it is smallest in bare rocks. Median patch size has increased mostly in mixed forests, related to the high decrease of representation of small fragments of this vegetation type. Patch standard size deviation was highest among coniferous forests before the calamity, it is highest among complete clearings after. Arable land is among units with approximately same size of sites with a deviation of 0.5. Total edge is logically highest for road and railway networks and lowest typically for bare rocks and peatbogs. Among forest units, broad-leaved forests have the smallest boundaries $(10,780 \mathrm{~m})$. Edge density has been affected by the calamity only to a very little extent. It is highest for road and railway networks 


\begin{tabular}{|c|c|c|c|c|c|c|c|}
\hline \multicolumn{2}{|c|}{$\mathrm{TE}$} & \multicolumn{2}{|c|}{ ED } & \multicolumn{2}{|c|}{ MPE } & \multicolumn{2}{|c|}{ MSI } \\
\hline before & after & before & after & before & after & before & after \\
\hline $49,398.92$ & $49,398.92$ & 420.93 & 420.93 & 498.98 & 498.98 & 46.06 & 46.06 \\
\hline $145,367.64$ & $147,240.43$ & $2,376.38$ & $2,376.80$ & $10,383.40$ & $10,517.17$ & $1,327.59$ & $1,327.45$ \\
\hline $10,726.45$ & $10,528.48$ & 541.63 & 542.48 & 825.11 & 752.03 & 185.41 & 170.71 \\
\hline $16,216.04$ & $16,417.30$ & 516.63 & 519.58 & $1,474.19$ & $1,368.11$ & 263.13 & 243.39 \\
\hline $1,264.90$ & $1,762.39$ & 704.29 & 431.75 & 421.63 & 440.60 & 314.62 & 218.07 \\
\hline $67,355.00$ & $38,174.80$ & 383.74 & 346.42 & 647.64 & 720.28 & 48.88 & 68.61 \\
\hline $13,899.24$ & $10,780.02$ & 181.20 & 222.87 & $1,985.61$ & $2,156.00$ & 226.71 & 310.00 \\
\hline $310,512.42$ & $170,655.99$ & 68.34 & 186.24 & $5,971.39$ & $2,160.20$ & 88.59 & 71.36 \\
\hline $43,444.25$ & $6,373.81$ & 123.97 & 192.40 & $2,286.54$ & $3,186.91$ & 122.14 & 553.70 \\
\hline $3,586.51$ & $3,586.51$ & 155.11 & 155.11 & $1,793.26$ & $1,793.26$ & 372.92 & 372.92 \\
\hline $65,659.53$ & $108,555.38$ & 324.98 & 370.53 & $1,025.93$ & 969.24 & 72.18 & 56.63 \\
\hline - & $311,470.27$ & - & 101.24 & - & $3,539.43$ & - & 63.83 \\
\hline- & $161,723.86$ & - & 256.97 & - & $1,347.70$ & - & 53.72 \\
\hline- & $45,116.68$ & - & 296.47 & - & $1,074.21$ & - & 87.08 \\
\hline- & $14,722.93$ & - & 168.87 & - & $1,132.53$ & - & 121.29 \\
\hline 460.32 & 460.32 & $1,214.56$ & $1,214.56$ & 460.32 & 460.32 & 747.72 & 747.72 \\
\hline 655.51 & 813.38 & 418.32 & 470.44 & 327.75 & 271.13 & 261.83 & 206.19 \\
\hline $3,004.35$ & $3,004.35$ & 138.56 & 138.56 & $1,502.18$ & $1,502.18$ & 322.60 & 322.60 \\
\hline
\end{tabular}

Table 4 - Disturbation rate of forests and semi-natural land cover areas towards types of natural landscape structure

\begin{tabular}{|lrrrrrr|}
\hline $\begin{array}{l}\text { Code } \\
\text { (see fig. 3) }\end{array}$ & Area (\%) & $\begin{array}{l}\text { Artificial } \\
\text { and agri- } \\
\text { cultural } \\
\text { areas }(\%)\end{array}$ & $\begin{array}{l}0-\text { undis- } \\
\text { turbed }(\%)\end{array}$ & $\begin{array}{l}1-\text { locally } \\
\text { disturbed } \\
(\%)\end{array}$ & $\begin{array}{l}2-\text { sig- } \\
\text { nificantly } \\
\text { disturbed } \\
(\%)\end{array}$ & $\begin{array}{l}\text { 3-com- } \\
\text { pletelly } \\
\text { disturbed } \\
(\%)\end{array}$ \\
\hline 1 & 3.381 & 14.41 & 13.93 & 7.14 & 9.58 & 54.94 \\
2 & 1.581 & 2.41 & 20.33 & 3.24 & 14.26 & 59.77 \\
3 & 3.896 & 8.08 & 9.90 & 9.92 & 10.87 & 61.24 \\
4 & 0.075 & 0.00 & 99.94 & 0.06 & 0.00 & 0.00 \\
5 & 8.688 & 10.48 & 12.07 & 4.03 & 12.28 & 61.15 \\
6 & 0.078 & 0.00 & 24.90 & 0.00 & 7.07 & 68.03 \\
7 & 32.474 & 6.80 & 11.97 & 8.29 & 7.62 & 65.32 \\
8 & 0.165 & 1.03 & 0.00 & 6.18 & 17.87 & 74.91 \\
9 & 14.295 & 5.77 & 9.81 & 3.05 & 6.56 & 74.81 \\
10 & 8.558 & 3.37 & 23.35 & 5.47 & 9.40 & 58.41 \\
11 & 26.128 & 4.08 & 39.68 & 4.86 & 18.52 & 32.84 \\
12 & 0.265 & 0.00 & 71.60 & 0.00 & 20.95 & 7.44 \\
13 & 0.385 & 0.00 & 100.00 & 0.00 & 0.00 & 0.00 \\
14 & 0.028 & 0.00 & 100.00 & 0.00 & 0.00 & 0.00 \\
\hline
\end{tabular}


Table 5 - Land cover metrics for types of primary landscape structure

\begin{tabular}{|rrrrrrrrrr}
\hline \multirow{2}{*}{ Code (see fig. 3) } & \multicolumn{2}{c}{ NUMP } & \multicolumn{2}{c}{ MPS } & \multicolumn{2}{c}{ MEDPS } & \multicolumn{2}{c}{ PSSD } \\
\cline { 2 - 10 } & before & after & before & after & before & after & before & after \\
\hline 1 & 67 & 83 & 2.84 & 2.29 & 0.46 & 0.50 & 4.96 & 3.85 \\
\hline 2 & 54 & 83 & 1.65 & 1.07 & 0.11 & 0.14 & 4.02 & 2.75 \\
\hline 3 & 95 & 103 & 2.31 & 2.13 & 0.58 & 0.79 & 4.02 & 3.77 \\
\hline 4 & 3 & 3 & 1.41 & 1.41 & 1.58 & 1.58 & 1.07 & 1.07 \\
\hline 5 & 55 & 86 & 8.89 & 5.68 & 0.44 & 1.12 & 33.01 & 12.30 \\
\hline 6 & 3 & 4 & 1.47 & 1.10 & 0.45 & 0.70 & 1.76 & 1.17 \\
\hline 7 & 276 & 341 & 6.62 & 5.35 & 0.94 & 1.11 & 23.09 & 18.50 \\
\hline 8 & 4 & 6 & 2.32 & 1.55 & 1.37 & 0.87 & 2.51 & 1.74 \\
\hline 9 & 144 & 208 & 5.59 & 3.87 & 0.60 & 0.63 & 20.54 & 17.33 \\
\hline 10 & 77 & 163 & 6.25 & 2.95 & 1.06 & 0.75 & 13.42 & 7.03 \\
\hline 11 & 140 & 266 & 10.50 & 5.52 & 0.71 & 1.10 & 34.47 & 13.70 \\
\hline 12 & 1 & 6 & 14.93 & 2.49 & 14.93 & 1.32 & 0.00 & 3.64 \\
\hline 13 & 2 & 2 & 10.84 & 10.84 & 10.84 & 10.84 & 8.82 & 8.82 \\
\hline 14 & 3 & 3 & 0.58 & 0.58 & 0.16 & 0.16 & 0.60 & 0.60 \\
\hline
\end{tabular}

units and lowest for complete clearings. Mean patch edge is almost unchanged after the calamity either. It is highest for road and railway networks units and lowest for peatbogs. Areas of broad-leaved and coniferous forests have the value of approximately $2,160 \mathrm{~m}$. Mean shape index is not significantly affected by the calamity. Road and railway networks units are mostly deviated from the ideal, circled shape, the least deviation is among settlement areas. Among areas with forests vegetations, transitional shrubs have the lowest value.

\subsection{Evaluation of land cover disturbation towards natural landscape structure}

In the following analyses, we compared spatial portion of particular forest and semi-natural areas of land cover after the effects of the windstorm had been processed, to the heterogeneity of natural land structure (Fig. 3). We took off artificial and agricultural areas from the analyses. As undisturbed, we understood contemporary areas of compact broad-leaved, coniferous and mixed forests. Locally disturbed were coniferous forests with local clearings, clearings with individual trees were significantly disturbed. Areas of complete clearings and unprocessed wood mass show entire damage by wind.

Among the most damaged areas were the geochores of glacifluvial forms with spruce and fir. Forests in the geochores of polygenetic forms with waterlogged spruce forests were also among the most damaged areas. Vegetation in moraines was less damaged (Table 4). The least damaged forests are in the geochores of fault slopes and polygenetic forms on glacial sediments that have only small proportion in the studied area, but their high resistance and resilience were demonstrated by the research in surrounding areas (Minár et al. 


\begin{tabular}{rrrrrrrrrr}
\hline \multicolumn{1}{c}{ TE } & \multicolumn{2}{c}{ ED } & \multicolumn{2}{c}{ MPE } & \multicolumn{2}{c}{ MSI } \\
\hline \multicolumn{1}{c}{ before } & \multicolumn{1}{c}{ after } & before & after & before & after & before & after \\
\hline $74,877.06$ & $80,243.15$ & 393.58 & 422.09 & $1,117.57$ & 966.78 & 2.31 & 2.23 \\
\hline $37,554.30$ & $47,773.57$ & 422.08 & 536.94 & 695.45 & 575.59 & 2.01 & 2.02 \\
\hline $91,612.49$ & $97,560.70$ & 417.84 & 444.97 & 964.34 & 947.19 & 2.09 & 2.05 \\
\hline $1,397.25$ & $1,397.25$ & 329.59 & 329.59 & 465.75 & 465.75 & 1.70 & 1.70 \\
\hline $75,491.65$ & $113,658.97$ & 154.42 & 232.60 & $1,372.58$ & $1,321.62$ & 2.34 & 2.07 \\
\hline $1,502.85$ & $1,971.81$ & 340.90 & 447.28 & 500.95 & 492.95 & 1.41 & 1.61 \\
\hline $389,977.95$ & $457,778.78$ & 213.43 & 250.77 & $1,412.96$ & $1,342.46$ & 2.38 & 2.16 \\
\hline $2,786.42$ & $4,130.20$ & 300.13 & 444.86 & 696.61 & 688.37 & 1.76 & 1.81 \\
\hline $162,138.40$ & $192,294.74$ & 201.58 & 239.09 & $1,125.96$ & 924.49 & 2.11 & 2.09 \\
\hline $89,470.48$ & $136,466.99$ & 185.81 & 283.41 & $1,161.95$ & 837.22 & 2.28 & 1.96 \\
\hline $197,206.35$ & $351,202.13$ & 134.14 & 239.04 & $1,408.62$ & $1,320.31$ & 2.40 & 2.05 \\
\hline $2,338.28$ & $4,745.24$ & 156.61 & 317.81 & $2,338.28$ & 790.87 & 1.71 & 1.58 \\
\hline $3,004.35$ & $3,004.35$ & 138.56 & 138.56 & $1,502.17$ & $1,502.17$ & 1.42 & 1.42 \\
\hline 813.38 & 813.38 & 470.34 & 470.34 & 271.13 & 271.13 & 1.18 & 1.18 \\
\hline
\end{tabular}

2009). Vegetation of the fluvial land systems belong to relatively less damaged areas. Trees were less damaged by the wind on lee slopes with high gradient and in the depressions sheltered from the air-mass blows. We also explored changes of selected land cover metrics on various types of geochores. Changes in the number of patches were most significant in the case of the geochores of glacifluvial forms and moraines. A significant decrease of MPS and increase of MEDPS was found in the case of the polygenetic and moraine geochores. At the sites of fault slopes, this occurence was caused by overlapping with border zones of local glades. Density of borders of the patches also increased significantly in moraines and polygenetic forms (Table 5).

\section{Discussion}

Major windstorms are important disturbance drivers in forest dynamics (Thomas et al. 2011). They can initiate ground layer successions (Peterson, Carson 1996) which are visible also in our model area. The catastrophic wind damage did not uniformly affect the landscape. The river flats were not among the much protected sites as their aspect was almost aligned with the wind. Everham and Brokaw (1996) assume that dryer soil conditions on ridge tops and slopes lead to a more developed root system of trees. Wet forest stands of the glacifluvial geochores with shallow roots were more impacted by the windthrows. Slightly inclined slopes were also sites of turbulent airflows.

We investigated the levels of wind disturbances in land cover categories of woods and cleanings and the windstorm impact on various types of natural landscape structure. Given results bring a ground for mapping the spatial structure of biotopes. Maps of land cover changes have been applied for evalu- 
ation of the level of damage of vegetation by the wind of various types of sites (Minár et al. 2009). Drawing on this research, we verified the highest level of damage among the polygenetic, glacifluvial and morenic sites (e.g. saddles, moraine elevations, and moderately down-swept colluvial slopes) covered by spruce monocultures. The smallest level of damage was among the sites of highly down-swept fault slopes covered by natural spruce woods, and in the depressions with broad leaved vegetation. The level of damage has been especially affected by the distance from baseline, orientation towards valley line, gradient and aspect of slopes; naturalness of forests, soil depth and moisture, similarly to Mikita, Kolejka, Klimánek (2009). Conclusions of Kopecká, Nováček (2009) associating increase of the number of polygons and decrease of the area of coniferous and mixed woods were confirmed during our largescale research. By verifying our hypotheses, we concluded that although the windstorm damaged mostly the spruce monocultures in the foothill, the area of mixed forests was also decreased. Woods of the polygenetic and glacifluvial sites were notably disturbed.

\section{Conclusions}

In our paper, we briefly summarized methodological aspects of the research of land cover and the use of land cover metrics for the evaluation of its changes by the windstorm. We have identified changes of land cover after processing of the wind disaster impacts in the territory of the Tatra National Park in the area of Štrbské Pleso - Tatranská Lesná.

Size of the coniferous forests has been adjusted most significantly and the medium size of land cover areas has been diminished of one third. The wind impacted also broad-leaved and mixed forests. The highest level of damage is among the spruce monocultures at the glacifluvial and polygenetic sites. The density of patches edge and the edge of patches itself has increased. Floodplain forests and natural spruce woods were less damaged. The windstorm affected the incompact settlement build-up areas, and road and railway networks only to a very small extent. The number of patches with transitional shrubs, the closest to an ideal oval shape, has increased significantly. After the calamity the overall landscape structure has become more fragmented, more diverse in terms of physiognomic types of landscape.

\section{References:}

BASTIAN, O. (2000): Landscape classification in Saxony (Germany) - a tool for holistic regional planning. Landscape and Urban Planning, 50, pp. 145-155.

DOBROVOLNÝ, P., KEPRTOVÁ, K. (2006): Spatial analysis of damage caused by strong winds and gales in the Czech lands since ad 1500. Geografie, 111, No. 1, pp. 51-69.

EVERHAM, E.M., BROKAW, N.V.L. (1996): Forest Damage and Recovery from Catastrophic Wind. The Botanical Review, 62, No. 2, pp. 113-185.

FALŤAN, V., BÁNOVSKÝ, M. (2008): Changes in land cover in the area of Vyšné Hágy Starý Smokovec, impacted by the wind calamity in November 2004 (Slovakia). Moravian Geographical Reports, 16, No. 3, pp. 16-26.

FALŤAN, V., SAKSA, M. (2007): Zmeny krajinnej pokrývky okolia Štrbského plesa po veternej kalamite v novembri 2004. Geografický časopis, 59, No. 4, pp. 359-372. 
FERANEC, J., OŤAHEL, J. (1999): Mapovanie krajinnej pokrývky metódou CORINE v mierke 1:50 000: Návrh legendy pre krajiny programu Phare. Geografický časopis, 51, No. 1, pp. 19-44.

FERANEC, J., OŤAHEL', J. (2001): Krajinná pokrývka Slovenska. Veda, Bratislava, 124 pp.

FORMAN, R.T., GODRON, M. (1993): Krajinná ekologie. Academia, Praha, 583 pp.

KOPECKÁ, M., NOVÁČEK, J. (2009): Forest fragmentation in the Tatra Region in the period 2000-2006. Landform Analysis, 10, pp. 58-63.

LEITÃO A.B., AHERN J. (2002): Applying landscape ecological concepts and metrics in sustainble landsape planning. Landscape and Urban Planning, 59, pp. 65-93.

LUKNIŠ, M. (1968): Geomorphological map of the Vysoké Tatry Mts. and their foreland 1:50,000. Geologický ústav Dionýza Štúra, katedra fyzickej geografie PriF UK, Bratislava.

McGARIGAL, K. (2002): Landscape pattern metrics. In: El-Shaarawi, A.H., Piegorsh, W.W. (eds.): Encyclopedia of Environmetrics. Volume 2. John Wiley \& Sons, Sussex, pp. $1135-1142$.

MAZÚR, E., LUKNIŠ, M. (1980): Geomorfologické jednotky. In: Mazúr, E. (ed.): Atlas SSR. SAV, Slovenský úrad geodézie a kartografie, Bratislava, pp. 54-55.

MICHALKO J., BERTA J. (1980): Geobotanická mapa, 1:50 000, list M-34-101-C, autorský originál, Botanický ústav SAV, Bratislava.

MIKITA, T., KOLEJKA, J., KLIMÁNEK, M. (2009): Pokročilá analýza lesních polomů pomocí GIS. In: GIS Ostrava 2009 (25.-28.1.2009), Ostrava, http://gis.vsb.cz/GIS_Ostrava/ GIS_Ova_2009/sbornik/Lists/Papers/108.pdf, cit. 27.04.2009.

MIKLÓS, L., IZAKOVIČOVÁ, Z., eds. (2006): Atlas reprezentatívnych geoekosystémov Slovenska. Esprit, Banská Štiavnica, 123 pp.

MINÁR, J., FALŤAN, V., BÁNOVSKÝ, M., DAMANKOŠOVÁ, Z., KOŽUCH, M. (2009): Influence of site conditions on the windstorm impact: A case study of the High Tatras foothills in 2004. Landform Analysis, 10, pp. 95-101.

NEMČOK, J., BEZÁK, V., BIELY, A., GOREK, A., GROSS, P., HALOUZKA, R., JANÁK, M., KAHAN, Š., MELLO, J., REICHWALDER, P., ZELMAN, J. (1994): Geologická mapa Tatier 1:25 000, autorský originál. Geologický ústav Dionýza Štúra, Bratislava.

NOHL, W. (2001): Sustainable landscape use and aesthetic perception - preliminary reflections on future landscape aesthetics. Landscape and Urban planning, 54, pp. 223-237.

OŤAHEL', J., FERANEC, J., KOPECKÁ, M., BETÁK, J, HUSÁR, K. (2008): Landscape development (long term changes) assessment: case study of the Tatras region. In: Kabrda, J., Bičík, I. (eds.): Man in the landscape across frontiers: Landscape and land use change in Central European border regions. CD-ROM Conference Proceedings of the IGU/LUCC Central Europe Conference 2007, Slovenia - Austria - Slovakia - Czech Republic, August 28 - September 4, 2007. Faculty of Science, Charles University in Prague, pp. 134-145.

PETERSON, C.J., CARSON, W.P. (1996): Generalizing forest regeneration models: the dependence of propagule availibility on disturbance history and stand size. Canadian Journal of Forest Research, 26, No. 1, pp. 45-52.

SCHULTE, L.A., MLADENOFF, D.J., BURROWS, S.N., SICKLEY, T.A., NORDHEIM, E.V. (2005): Spatial controls of Pre-Euro-American wind and fire in northern Wisconsin (USA) forest landscapes. Ecosystems, 8, pp. 73-94.

SIU-NGAN LAM, N. (2008): Methodologies for Mapping Land Cover/Land Use and its Change. In: Liang, S. (ed.): Advances in Land Remote Sensing. Springer, Netherlands, pp. 341-367.

THOMAS, N.E., HUANG, CH., GOWARD, S.N., POWELL, S., RISHMAWI, K., SCHLEEWEIS, K., HINDS, A. (2011): Validation of North American Forest Disturbance dynamics derived from Landsat time series stacks. Remote Sensing of Environment, 115, No. 1, pp. 19-32.

ULANOVA, N.G. (2000): The effects of windthrow on forests at different spatial scales: a review. Forest Ecology and Management, 135, pp. 155-167.

Vysoké Tatry - ortofotomapa 1:25 000. Vojenský kartografický ústav, Harmanec 2004.

Vysoké Tatry - atlas ortofotomáp 1:15 000. Geodis, Brno, 2006.

ZIELONKA, T., MALCHER, P. (2009). The dynamics of a mountain mixed forests under wind disturbances in the Tatra Mountains, central Europe - A dendrochronological reconstruction. Canadian Journal of Forest Research 39, No. 11, pp. 2215-2223. 
ZHANG, L., WANG, H. (2006). Planning an ecological network of Xiamen Island (China) using landscape metrics and network analysis. Landcsape and Urban planning, 78, pp. 449-456.

\section{Zhrnutie}

\section{HODNOTENIE ZMIEN KRAJINNEJ POKRÝVKY PO MIMORIADNEJ VÍCHRICI S VYUŽITÍM KRAJINNOEKOLOGICKÝCH INDEXOV: PRÍKLADOVÁ ŠTÚDIA ÚPÄTIA VYSOKÝCH TATIER}

V súčasnom fyzickogeografickom i krajinnoekologickom výskume sa začínajú čoraz viac preferovat’ okrem kvalitatívnych i kvantitatívne metódy. Mapovanie krajinnej pokrývky spojené s aplikáciou metodík dial'kového prieskumu Zeme a nástrojov geografických informačných systémov poskytuje dostatok informácií použitelných pre štatistické analýzy zmien priestorovej štruktúry krajiny a jej využitia.

Víchrica spôsobila 19. novembra 2004 velké škody najmä v lesoch Tatranského národného parku v okolí tatranských osád. Podla prognóz klimatológov sa podobné situácie môžu vd’aka klimatickým zmenám v Strednej Európe v tomto storočí opakovat'. Cielom našej práce je charakterizovat' zmeny priestorovej štruktúry krajinnej pokrývky vybraného územia úpätia Vysokých Tatier v oblasti Štrbské Pleso - Tatranská Lesná na základe analýz stavu krajinnej štruktúry pred veternou kalamitou v novembri 2004 a po spracovaní jej následkov s využitím metodických postupov CORINE Land Cover a vybraných krajinnoekologických indexov. Tiež analyzujeme závislost’ týchto zmien na prírodnej (primárnej) krajinnej štruktúre. Modelové územie reprezentuje všetky typy krajinnej pokrývky najviac postihnutej oblasti.

Stav krajinnej pokrývky pred veternou kalamitou reprezentuje 14 typov priestorových jednotiek krajinnej pokrývky: nesúvislá sídelná zástavba, cestná siet a prilahlé plochy, železničná siet’ a prilahlé plochy, sídelná zeleň, športové areály, nezavlažovaná orná pôda, trvalé trávne porasty (lúky a pasienky), ihličnatý les, listnatý les, zmiešaný les, kosodrevina, prechodné lesokroviny, skaly, rašelinisko, vodné plochy, rozdelených v rámci 393 areálov. Po kalamite sme identifikovali 665 areálov krajinnej pokrývky a zaradili sme ich do 18 typologických jednotiek. Novými jednotkami vzniknutými riešením následkov kalamity boli typy: ihličnatý les s lokálnymi rúbaniskami, rúbaniská úplné, rúbaniská so stojacimi stromami, nespracovaná kalamita. Pre potreby hodnotenia náchylnosti prírodného prostredia na vznik polomov a vývratov sme analyzovali mieru poškodenia vegetácie 14 typov primárnej krajinnej štruktúry. Najvýraznejšie sa zmenšila plocha ihličnatých lesov a o tretinu sa zmenšila priemerná velkoste areálov krajinnej pokrývky. Víchrica zasiahla aj listnaté a zmiešané lesy. Najviac poškodené boli porasty smrekových monokultúr na geochórach polygenetických a glacifluviálnych foriem s kambizemami podzolovými. Narástla hustota okraja a dížka obvodov plôšok. K menej poškodeným patria prirodzené porasty smrekových lesov zlomových svahov a lužné lesy. Kalamitou boli minimálne poškodené urbanizované, technizované a polnohospodárske areály. Po spracovaní následkov kalamity sa rozšírili plochy areálov športu a zariadení volného času. Významne sa zväčšil počet plôšok s prechodnými lesokrovinami, ktoré zároveň majú tvar najbližší „ideálnemu“ oválnemu. Celkovo sa krajinná štruktúra stala po kalamite rozdrobenejšou, diverzifikovanejšou z hladiska fyziognomických typov krajiny a prejavuje sa tendencia k sekundárnej sukcesii.

Obr. 1 - Situačná mapa študovaného územia

Obr. 2 - Krajinná pokrývka skúmaného územia pred a po veternej kalamite. V legende: Urbanizované a technizované areály: nesúvislá sídelná zástavba, cestná a železničná siet a prilahlé areály, sídelná zeleň, areály športu a zariadení volného času. Polnohospodárske areály: nezavlažovaná orná pôda, trávne porasty (lúky a pasienky). Lesné a poloprírodné areály: listnaté lesy, ihličnaté lesy, zmiešané lesy, kosodrevina, prechodné lesokroviny, rúbaniská úplné, rúbaniská so stojacimi stromami, ihličnaté lesy s lokálnymi rúbaniskami, nespracovaná drevná hmota, skaly. Zamokrené areály: rašeliniská. Vody: vodné toky, vodné plochy. 
Obr. 3 - Prírodná (primárna) krajinná štruktúra skúmaného územia: 1 - holocénna dolinová niva, fluviálne sedimenty, fluvizeme, Alnenion glutinoso-incanae Oberd. 1962; 2 - holocénna dolinová niva, fluviálne sedimenty, fluvizeme, Eu-Vaccinio-Piceenion Oberd. 1957, 3 - erózny svah, glacifluviálne sedimenty, kambizem podzolová až podzol kambizemný, Vaccinio-Abietenion Oberd. 1962; 4 - polygenetická forma, glaciálne sedimenty, kambizem podzolová až podzol kambizemný, Vaccinio-Abietenion Oberd. 1962; 5 - polygenetická forma, deluviálne sedimenty, kambizem podzolová až podzol kambizemný, Vaccinio-Abietenion Oberd. 1962; 6 - polygenetická forma, deluviálne sedimenty, kambizem podzolová až podzol kambizemný, Piceion excelsae Pawlowski in Pawlowski et al. 1928; 7 - glacifluviálna forma, glacifluviálne sedimenty, kambizem podzolová až podzol kambizemný, Vaccinio-Abietenion Oberd. 1962; 8 - glacifluviálna forma, deluviálne sedimenty, kambizem podzolová až podzol kambizemný, Vaccinio-Abietenion Oberd. 1962; 9 - glacifluviálna forma, glacifluviálne sedimenty, kambizem podzolová až podzol kambizemný, Eu-Vaccinio-Piceenion Oberd. 1957; 10 - moréna, glaciálne sedimenty, kambizem podzolová až podzol kambizemný, Vaccinio-Abietenion Oberd. 1962; 11 - moréna, glaciálne sedimenty, kambizem podzolová až podzol kambizemný, Eu-Vaccinio-Piceenion Oberd. 1957; 12 - zlomový svah, granodiorit, kambizem podzolová až podzol kambizemný, Eu-Vaccinio-Piceenion Oberd. 1957; 13 - vodná plocha / horské jazero; 14 - rašelinisko, organické sedimenty, organozeme.

Authors' affiliations: V. Falt'an and M. Bánovský are affiliated with Comenius University in Bratislava, Faculty of Natural Sciences, Department of Physical Geography and Geoecology, Mlynská dolina 1, 84215 Bratislava, Slovakia; e-mail: faltan@fns.uniba.sk, banovsky@fns. uniba.sk. M. Blažek is affiliated with University of Dundee, School of Social and Environmental Sciences - Geography, Perth Road, Dundee, DD1 4HN, United Kingdom.

Initial submission, 5 November 2009; final acceptance, 17 March 2011.

\section{Please cite this article as:}

FALŤAN, V., BÁNOVSKÝ, M., BLAŽEK, M. (2011): Evaluation of land cover changes after extraordinary windstorm by using the land cover metrics: a case study on the high Tatras foothill. Geografie, 116, No. 2, pp. 156-171. 